\title{
ANALISIS AUDIT SISTEM INFORMASI BAGIAN TATA USAHA SMA AL-HIDAYAH WAY SEPUTIH LAMPUNG TENGAH
}

\author{
Yuda Septiawan \\ NPM 1611050099
}

Fakultas Komputer, IIB Darmajaya

yuda.1611050099@mail.darmajaya.ac.id

\begin{abstract}
Tata usaha sekolah adalah bagian dari unit pelaksana teknis penyelenggaraan sistem administrasi dan informasi pendidikan di sekolah. Informasi yang tata usaha sekolah kelola penting sebagai basis pelayanan dan bahan pengambilan keputusan sekolah. Semakin lengkap dan akurat data terhimpun maka pemberian pelayanan makin mudah dan pengembilan keputusan makin tepat.

Ditinjau dari sudut asal usul kata (etimologis), maka ADMINISTRASI berasal dari Bahasa Latin yaitu Ad+Ministrare. Ad berarti intensif, sedangkan Ministrare berarti melayani, membantu, dan memenuhi atau menyediakan (Husaini Usman, 2006).Menurut The Lian Gie (2000), tenaga tata usaha memiliki tiga peranan pokok yaitu:

1. melayani pelaksanaan pekerjaan-pekerjaan operatif untuk mencapai tujuan dari suatu organisasi,

2. menyediakan keterangan-keterangan bagi pucuk pimpinan organisasi itu untuk membuat keputusan atau melakukan tindakan yang tepat, dan

3. membantu kelancaran perkembangan organisasi sebagai suatu keseluruhan.

Berdasarkan pendapat The Lian Gie di atas, maka peranan tenaga administrasi sekolah sesungguhnya hanya satu yaitu sebagai administrator karena ketiga peranan yang diungkapkan di atas yaitu melayani, menyediakan, dan membantu sama dengan administrasi.
\end{abstract}

Kata Kunci : tata usaha 


\section{A. INTRODUCTION}

SMA Al-Hidayah Way Seputih berdiri diatas tanah wakaf pada tanggal 1 Juli 2006. Pada mulanya sekolah ini bukanlah sekolah melainkan pondok Pesantren, karena sesuatu hal maka Pesantren tersebut harus di pidahkan kepesantren yang lain. Dan berdirilah sekolah SMA AlHidayah Way Seputih sampai saat ini masih aktif

Bangunan semakin tahun semakin mengalami perubahan dimana dimulai dari 3 ruang belajar dan 1 ruang guru dan 1 rombongan belajar kemudian berkembang menjadi 3 rombel belajar dan menjadi beberapa ruang seperti :

1. 3 ruang belajar

2. 1 ruang guru

3. 1 ruang tata usaha

4. 1 ruang perpustakaan

5. 1 ruang kepala sekolah

6. 4 kamar mandi (4 Pria dan 4 ) perempuan
Ada pun kepala SMA AlHidayah sudah banyak mengalami pergantian seperti:

1. Bapak Mifta (2006-2007)

2. Bapak Agus (2007-2011)

3. Bapak Suyitno (2011-2012)

4. Ibuk Sri Wahyuni Ningsih S.Pd.MM (2012-Sekarang)

Dipandang dari sudut dunia pendidikan di kecamatan Way Seputih, sekolah ini merupakan satu-satunya Sekolah SMA Swasta di Way Seputih. SMA Al-Hidayah mempuyai satu jurusan yaitu IPA. Dan saat ini SMA AlHidayah terdaftar memiliki 90 siswa dan memiliki 18 tenaga pengajar (guru).

\section{Visi dan Misi}

a) Visi

Teladan dalam IMTAQ dan Disiplin menuju keunggulan prestasi, dengan indikator:

1. Terwujudnya warga sekolah yang agamis

2. Unggul dalam bidang kedisiplinan 
3. Unggul dalam bidang akademik

4. Unggul dalam bidang non akademik

\section{b) Misi}

1 Menumbuhkan penghayatan dan pengamalan terhadap ajaran agama yang dianut sehingga menjadi manusia yang beriman dan bertaqwa.

2.Menanamkan budaya disiplin dan tertib dalam kehidupan sekolah kepada segenap warga sekolah.

\section{Mengoptimalkan}

kompetensi siswa melalui ilmu pengetahuan dan teknologi.

\section{Mengembangkan}

pengetahuan

dan

keterampilan melalui

pengalaman langsung

sesuai dengan minat dan

bakat siswa.

$\begin{array}{cc}\text { 5.Bekerja sama } & \text { dengan } \\ \text { lembaga } & \text { terkait, }\end{array}$

masyarakat dalam pembinaan siswa melalui kegiatan intrakurikuler dan ekstrakurikuler.

6. Melengkapi sarana dan prasarana dan fasilitas pendidikan

\section{B. METHODS}

1. Deliver \& Support.

$\begin{array}{rr}\text { Domain } & \text { ini } \\ \text { menitikberatkan pada proses }\end{array}$ perencanaan dan penyelarasan strategi TI dengan strategi perusahaan, mencakup masalah strategi, taktik dan identifikasi tentang bagaimana TI dapat memberikan kontribusi maksimal terhadap pencapaian tujuan bisnis organisasi sehingga terbentuk sebuah organisasi yang baik dengan infrastruktur teknologi yang baik pula. Dan memastikan layanan yang ada berjalan sesuai dengan tujuan. Serta adanya pelatihan bagi para pengguna internal dan eksternal

Domain ini mencakup :

DS4 - Memastikan layanan yang berkelanjutan

DS7 - Mendidik dan melatih pengguna 


\section{RESULT}

1. Hasil rekapan kuisioner user

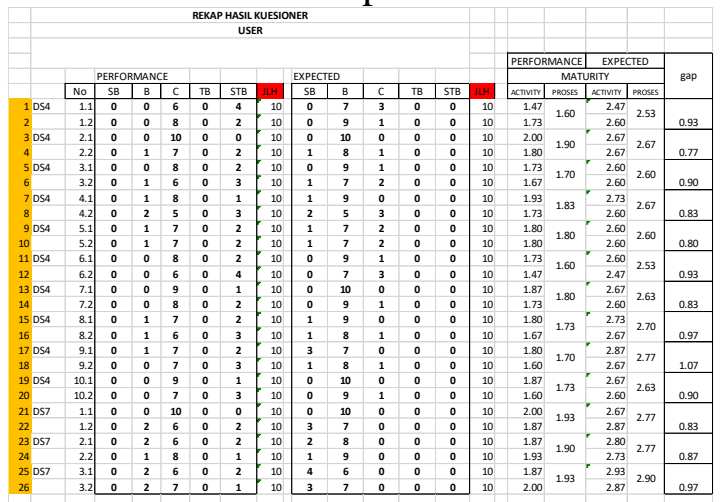

2. Hasil rekapan kuisioner manajemen

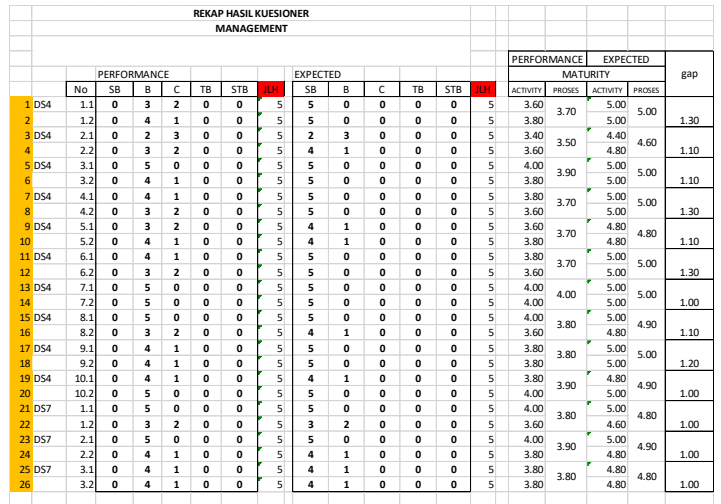

\section{Hasil}
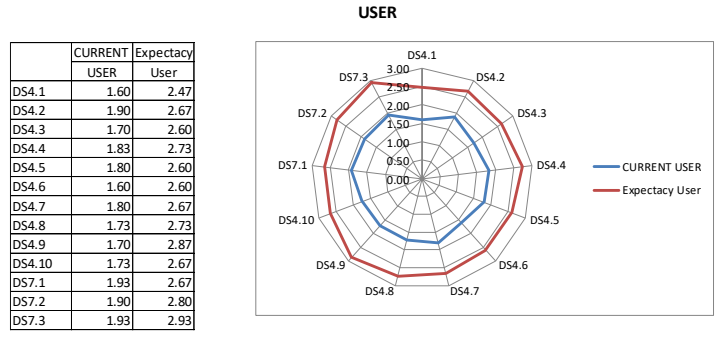
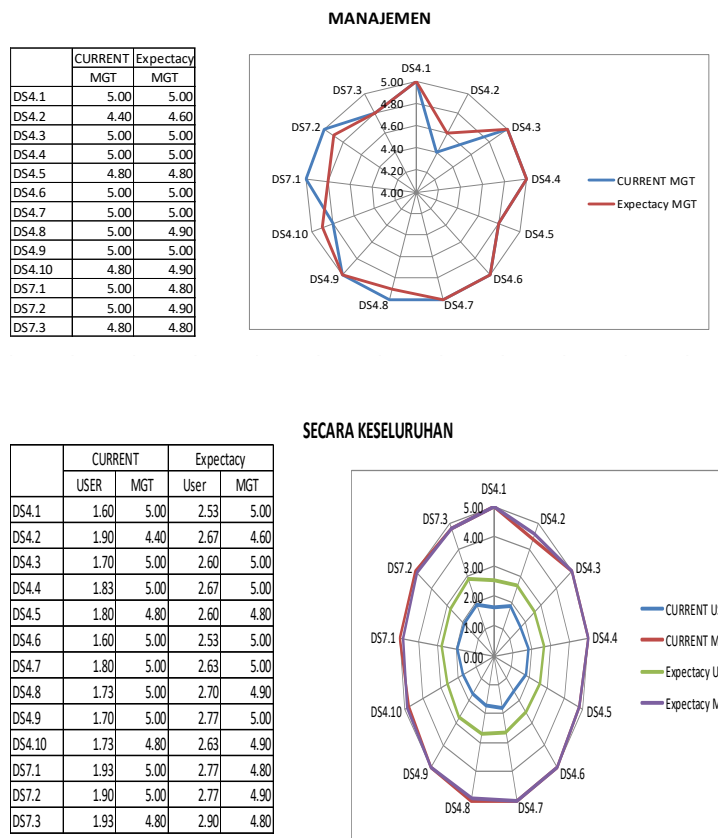

SECARA KESELURUHAN

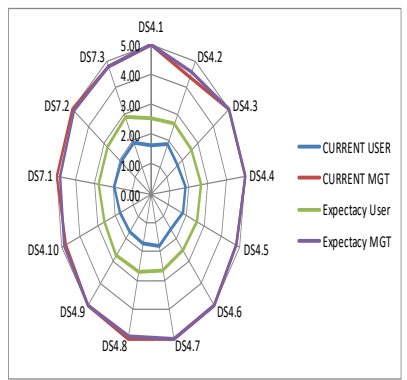

\section{DISCUSSION}

Pengembangan Tata Usaha

sebenarnya merupakan salah

satu upaya untuk meningkatkan

kualitas pendidikan. Ia sebagai

instrumen yang membantu

praktisi pendidikan untuk

memenuhi kebutuhan peserta

didik dan kebutuhan

masyarakat. Caswell

menyatakan bahwa

pengembangan Tata Usaha

merupakan alat untuk

membantu guru melakukan

tugasnya mengajar dan

memenuhi kebutuhan

masyarakat. Pengembangan 
Tata Usaha tidak pernah berhenti, ia merupakan proses yang berkelanjutan dan proses siklus yang terus menerus sejalan dengan perkembangan dan tuntutan perubahan masyarakat.

Kajian-kajian pada pengembangan yang bersifat filosofis, psikologis, situasi sosial politis, dan perkembangan iptek menjadi sangat penting ketika dikehendaki perubahan perubahan dan pengembangan pendidikan masa depan.pertinbangan-

pertimbangan tentang pentingnya relevansi, fleksibilitas, dan kontinuitas merupakan prinsip-prinsip yang perlu dipertimbangkan dalam pengembangan Tata Usaha.

\section{E. REFERENCE (Based ISO 690 )}

Majid, Abdul. (2014). Pembelajaran Tematik Terpadu.Bandung: PT Remaja Rosdakarya Depdiknas.(2009). Tata Usaha Tingkat Satuan Pendidikan.
Jakarta: Pusat Tata Usaha, Balitbang Depdiknas

Hamalik, O (2004). Tata Usaha dan Pembelajaran.Bandung: Bumi Aksara

Kemendikbud.(2013).Panduan

Penilaiandi Sekolah Dasar. Jakarta: Dirjen Pendidikan Dasar

Kunandar, 2011 "Guru Profesional Implementasi KTSP dan Sukses dalam Sertifikasi Guru". Jakarta Utara : PT Rajagrafindo Persada.

Manshur Muslich (2008).Tata Usaha Tingkat Satuan Pendidikan, Jakarta: Bumi

Republik Indonesia.. (2013). Peraturan Menteri Pendidikan dan Kebudayaan Nomor81A Tahun 2013 tentang Implementasi Tata Usaha Subandijah. 1992. Pengembangan dan Inovasi Tata Usaha. Jakarta: Raja Grafindo Persada.

[1] A. S. Putra And O. M. Febriani, "Knowledge Management Online Application In Pdam Lampung Province," In Prosiding International Conference On Information Technology And Business (Icitb), 2018, Pp. 181-187.

[2] A. S. Putra, O. M. Febriani, And B. Bachry, "Implementasi Genetic Fuzzy System Untuk Mengidentifikasi Hasil Curian Kendaraan Bermotor Di Polda Lampung," J. Sist. Inf. Dan Manaj. Basis Data, Vol. 1, No. 1, Pp. 21-30, 2018.

[3] O. M. Febriani And A. S. Putra, "Sistem Informasi Monitoring Inventori Barang Pada Balai 
IIB Darmajaya

Riset Standardisasi Industri Bandar Lampung," J. Inform., Vol. 13, No. 1, Pp. 90-98, 2014.

[4] Putra, Arie Setya. "2018 Artikel Struktur Data, Audit Dan Jaringan Komputer." (2018).

[5] Putra, A. S. (2018, July 17). Paperplain Fundamental Create Application With Borland Delphi 7.0 University Of Mitra Indonesia. Retrieved From Osf.Io/Pbrn9.

\section{E. REFERENCE (Based APA )}

Putra, A. S., Aryanti, D. R., \& Hartati, I. (2018, November). Metode SAW (Simple Additive Weighting) sebagai Sistem Pendukung Keputusan Guru Berprestasi (Studi Kasus: SMK Global Surya). In Prosiding Seminar Nasional Darmajaya (Vol. 1, No. 1, pp. 85-97).

Sari, D. P., Febriani, O. M., \& Putra, A. S. (2018, November). Perancangan Sistem Informasi SDM Berprestasi pada SD Global Surya. In Prosiding Seminar Nasional Darmajaya (Vol. 1, No. 1, pp. 289-294).

Putra, A. S. (2018). Paperplain: Execution Fundamental Create Application With Borland Delphi 7.0 University Of Mitra Indonesia.

Putra, A. S., Sukri, H., \& Zuhri, K. Sistem Monitoring Realtime Jaringan Irigasi Desa (JIDES) Dengan Konsep Jaringan Sensor Nirkabel. IJEIS (Indonesian Journal of Electronics and Instrumentation Systems), 8(2), 221232.
Darmawan, A., Yuliawati, D., Marcella, O., \& Firmandala, R. (2016). Sistem Absensi dan Pelaporan Berbasis Fingerprint dan SMS Gateway. EXPLORE, 7(1).

Febriani, O. M., Wahyuni, T., \& Yusuf, S. (2017). DESIGN OF WEBSITEBASED INFORMATION SYSTEM FOR EDOCUMENT ADMINISTRASI IN THE COMMUNITY SERVICE UNIT (A Case Study at Rajabasa District). INTERNATIONAL JOURNAL OF COMPUTERS \& TECHNOLOGY, 16(7), 7010-7020.

Febriani, O. M., \& Wahyuni, T. (2017, October). PERANCANGAN SISTEM E-DOCUMENT ADMINISTRASI LOGBOOK PENELITIAN PADA UNIT LAYANAN DI BANDAR LAMPUNG. In Prosiding Seminar Nasional Darmajaya (Vol. 1, No. 1, pp. 187-194).

Febriani, O. M., \& Permadi, A. B. (2017). Implementasi Sistem Aplikasi Data Bimbingan dan Pelanggaran Siswa pada Sekolah Menengah Atas di Lampung Tengah dengan Metode Analisis dan Desain Sistem Terdistribusi (SSAD). EXPERT, 7(1).

Febriani, O. M., \& Ambarwati, L. (2015). PERANCANGAN APLIKASI PENGOLAHAN DATA PENJUALAN UKM KELANTING KHAS TELO DESA SIDOHARJO KECAMATAN JATI AGUNG KABUPATEN LAMPUNG SELATAN. Jurnal Teknologi Informasi dan Bisnis Pengabdian Masyarakat Darmajaya, 1(1), 77-95. 
Febriani, O. M. (2015). Rancang Bangun Aplikasi Ecommercemenggunakan Freewebstore pada UKM Kelanting di Desa Sidoharjo Lampung Selatan. Prosiding Sembistek 2014, 1(02), 446-458.

https://haendra.wordpress.com/2012/0 6/08/pengertian-cobit/ 